\title{
Preparation and utilisation of fish silage as feed supplement for ruminants
}

\author{
A Guerouali, M Zahar, N Benkerroum \\ Institut Agronomique et Vétérinaire Hassan II, Rabat, Morocco
}

Large quantities of wastes are generated from seafood processing and urban fish markets. Disposal of these wastes presents a major problem because of their odor and high moisture content. As the world demand for protein increases it is desirable that fish wastes are not discarded, but would be converted, if possible, into protein sources for livestock feeding.

The present study was conducted to prepare fish silage by natural fermentation when sugar cane molasse was used to aid the growth of micro-organisms. Fresh marine fish wastes (viscera, heads and frames of various species) were collected from the fish market of the Rabat city. Upon arrival to the laboratory, the fish waste was shopped then mixed in a silo with sugar cane molasse in $1: 1$ ratio. The content of the silo was stirred daily on a regular basis. A natural fermentation took place and the $\mathrm{pH}$ of the mixture dropped from 5.8 to 4.5 in two weeks giving to the product an acidic smell. The fish silage (composed of $26.7 \%$ crude proteins, $30.2 \%$ soluble sugars, $18.2 \%$ ash and $7.5 \%$ lipids) was mixed with wheat bran (19\%) and minerals and vitamins (1\%). Fish silage blocks of about $8 \mathrm{~kg}$ were made and dried under the sun for several days.

The fish silage product was introduced in the diet of growing lambs and dairy cattle as nutrients supplement, and was compared to the most commonly used commercial feed supplement (table). No significant difference was observed in average daily growth of lambs. However, in dairy cattle, cows fed the new product produced $10 \%$ more milk when compared to cows fed the commercial feed (barley $70 \%$, Sunflower meal $29 \%$ and Minerals and vitamins $1 \%$ ).

$\begin{array}{lcc}\text { Rations }(\mathrm{g} / \mathrm{A} / \mathrm{d}) & \text { fish silage ration } & \text { sunflower ration } \\ \text { Barley grains } & 300 & 300 \\ \text { Sunflower meal } & - & 200 \\ \text { Fish silage meal } & 200 & - \\ \text { Wheat straw } & 300 & 300 \\ \text { Minerals and vitamins } & 10 & 10 \\ \text { Number of lambs } & 20 & 20 \\ \text { Trial duration }(\mathrm{d}) & 60 & 60 \\ \text { Initial weight }(\mathrm{kg}) & 17.2 & 17.1 \\ \text { Final weight }(\mathrm{kg}) & 23.2 & 22.9 \\ \text { Daily weight gain }(\mathrm{g}) & 98 & 97\end{array}$

